Original Article

\title{
Recurrence of hepatitis $C$ virus after treatment with pegylated interferon and direct acting antivirals in Punjab Pakistan
}

\author{
Recorrência do vírus da hepatite $C$ após tratamento com interferon peguilado e \\ antivirais de ação direta em Punjab, Paquistão
}

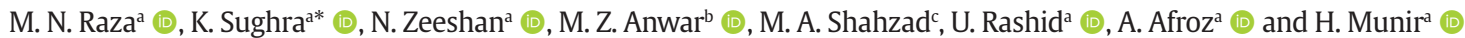 \\ aUniversity of Gujrat, Department of Biochemistry and Biotechnology, Gujrat, Punjab, Pakistan \\ bDepartment of Biochemistry, Combined Military Hospital, Kharian Medical College, Kharian, Punjab, Pakistan \\ cDepartment of Anesthesia, Major Shabeer Shareef THQ Hospital, Kunjah, Punjab, Pakistan
}

\begin{abstract}
Although increased response rates concomitant in hepatitis $C$ virus but relapse after treatment is threatened. Therefore, it is terrible requirement to evaluate the response of Pegylated interferon and direct acting antivirals in Punjab Pakistan. The study was conducted to find the rate of recurrence of HCV infection after treatment with Pegylated Interferon and Direct Acting Antivirals in Punjab Pakistan. This study was conducted at Department of Pathology, Nawaz Sharif Medical College Gujrat, while treatment effects monitored in different Government and Private Hospitals of Punjab, Pakistan. Total 973 patients who administered the recommended dose and divided in two groups (i) Interferon based therapy (ii) direct acting antivirals (DAAs).Other parameters like ALT and viral load studied. The rate of recurrence was higher in female infected with genotype $2 b$ and in male with mixed genotype 3a/2b after six month of antiviral therapy. Genotype 3a showed significant response to therapy after three month. 32 among 374 (8.5\%) were positive after 24 weeks of treatment with interferon, 29 (7.7\%) patients have same genotype while 3 patients were re-infected with different HCV strains. With DAAs, only 27 (4.8\%) patients were positive among 558 after 2 weeks and one patient re-infected with different genotype. Early and sustained virological response noted in DAAs. ALT and viral load decreased faster with DAAs that not achieved after 4 weeks with pegylated interferon. Sustained virological response appears in DAAs and recurrence rate is high in interferon therapy compared to DAAs. Therefore, reinfection has implications for correct treatment efficiency and to select strategies for retreatment cases.
\end{abstract}

Keywords: hepatitis C virus, sustained virologic response, recurrence, direct acting antivirals.

\begin{abstract}
RESUMO
Embora aumentem as taxas de resposta concomitantes no vírus da hepatite C (HCV), há risco de recidiva após o tratamento. Portanto, é um requisito terrível avaliar a resposta do interferon peguilado e antivirais de ação direta em Punjab, Paquistão. O estudo foi conduzido para encontrar a taxa de recorrência da infecção por HCV após o tratamento com interferon peguilado e antivirais de ação direta em Punjab, Paquistão. Este estudo foi conduzido no Departamento de Patologia Nawaz Sharif Medical College Gujrat, enquanto os efeitos do tratamento foram monitorados em diferentes hospitais públicos e privados de Punjab, Paquistão. Total de 973 pacientes que administraram a dose recomendada foram divididos em dois grupos: (i) Terapia baseada em interferon, (ii) antivirais de ação direta (DAAs). Outros parâmetros como ALT e carga viral foram estudados. A taxa de recorrência foi maior em mulheres infectadas com o genótipo $2 \mathrm{~b}$ e em homens com genótipo misto 3a / 2b após seis meses de terapia antiviral. 0 genótipo 3a mostrou resposta significativa à terapia após três meses. 32 entre 374 (8,5\%) foram positivos após 24 semanas de tratamento com interferon, 29 (7,7\%) pacientes têm o mesmo genótipo, enquanto 3 pacientes foram reinfectados com diferentes cepas de HCV. Com DAAs, apenas 27 (4,8\%) pacientes foram positivos entre 558 após duas semanas e um paciente reinfectado com genótipo diferente. Resposta virológica precoce e sustentada observada em DAAs. ALT e carga viral diminuíram mais rapidamente com DAAs, que não alcançou após 4 semanas com interferon peguilado. A resposta virológica sustentada aparece em DAAs, e a taxa de recorrência é alta na terapia com interferon em comparação com DAAs. Portanto, a reinfecção tem implicações para a eficiência do tratamento correto e para selecionar estratégias para casos de retratamento.
\end{abstract}

Palavras-chave: vírus hepatite C, resposta virológica sustentada, recorrência, antivirais de ação direta.

*e-mail: kalsoom.sughra@uog.edu.pk

Received: May 26, 2021 - Accepted: July 01, 2021 


\section{Introduction}

Hepatitis $C$ virus is global health issue that has infected approximately 71 million people worldwide. It has become the seventh, among leading cause of death throughout the world (Naghavi et al., 2014; WHO, 2017). The international community noted the increased hepatitis mortality rate and United Nations include it in Sustainable Development Aims (Waheed, 2015a). Global Health Sector Strategy (GHSS) constituted by World Health Organization (WHO) that have claimed to control viral hepatitis until 2030. If GHSS will succeed then incidence of hepatitis will decreased to $90 \%$ and mortality rate at level of $65 \%$ till 2030 (WHO, 2016). Almost 10 million cases of hepatitis $C$ virus are now present in Pakistan (Saeed et al., 2015; Waheed et al., 2017). Contaminated blood, unsterilized surgical and dental instruments, reuse contaminated needles and shaving from barbers are major routes of hepatitis transmission (Waheed et al., 2009). Only $1 \%$ among all positive hepatitis $C$ virus patients are being treated in Pakistan and mostly are poor people that cannot afford this treatment. There are seven main genotypes and eighty six subtypes throughout the world while genotype 3a is most dominant in Pakistan (Messina et al., 2015; Smith et al., 2014).The interferon and Ribavirin was only the best therapy choice for hepatitis C virus patients from 2000 to 2011 (Waheed, 2015b). The vital purpose of antiviral therapy was to achieve the target of RNA lower than detection limit that will reduce the chance of getting hepatocellular carcinoma and cirrhosis. Therapy response was dependent on host along with other factors such as age, function of liver, concentration of viral load and genotypes. Severe adverse effects were noted with use of combination therapy and target response was very limited. The response rate was $63 \%$ with interferon and ribavirin treatment while $75 \%$ using pegylated interferon and ribavirin therapy (Aziz et al., 2012).

The Association known as Asia Pacific Association that Studied on Liver recommended the drug Sofosbuvir along with Ribavirin for the treatment who are infected by Hepatitis C Virus genotype 3a (Omata et al., 2016). The direct antiviral agents (DAAs) therapy has radically increased the rate of sustained virological response (SVR) to greater than $90 \%$ in patients that are leaving with chronic Hepatitis C Virus infection. In order to define true treatment efficacy and determined most suitable retreatment for patients whom HCV removed in treatment and infected with new HCV strain later on. It is highly important to differentiate between virologic relapse and reinfection. As patients, immunity is not protecting from reinfection after consequent exposure and it reported by various studies. The Purpose of this study was to evaluate the rate of relapse after treatment with old and new treatment therapies and comparison of response of these therapies against $\mathrm{HCV}$.

\section{Materials and Methods}

The designed study included a comprehensive protocol for research at department of Pathology, Nawaz Sharif Medical College, University of Gujrat. A total 973 patients of recurrence of HCV were admitted from July 2017 to January 2019. The samples for Liver Function Tests (LFTs), viral load $(\mathrm{IU} / \mathrm{ml})$ and genotypes were collected from various points of Punjab. Most important parameters like ALT and ALP were performed in LFTs. The reagents of ALT kits were ALT assay buffer, Enzyme Mix, Substrate, Standards and Fluorescent Peroxidase Substrate. The 932 patients complete the treatment while 41 patients discontinue during treatment. Genotyping analyses were performed by using Amplisens Genotyping kit, Russia (including: PCR $\operatorname{mix}(1)$ FRT (1b/3, 1a/2, 4/IC), RTPCR Mix (2) FRT/FEP, TaqF, PC 1b/3, PC 1a/2, PC 4, Buffer T.E and N.C) and viral load by using the AJ Roboscreen (Germany) on RT PCR (Step one, Applied Biosystems, USA). These patients were classified in two groups according to therapy: (i) Interferon based therapy (ii) direct acting antivirals (DAAs) to evaluate their response and frequency of rate of recurrence. Sustained virological response was set an important parameter to check the response of therapies. Complete follow up for 2 years of all these patients was maintained. Statistical analyses performed for continuous variables reported as mean \pm standard deviation, response rate of DAAs and interferon-based therapy was measured by using bar chart as appropriate. These analyses performed by using Minitab version 17 and $P$ value less than 0.05 denoted as statistical significance. Furthermore, the difference in distributions of covariates analyzed between DAAs and Interferon (IFN) based therapies. This study approved by institutional (University of Gujrat, Punjab, Pakistan) ethical committee and conducted according to the Declaration of Helsinki. A Written informed consent was taken from all patients before participating in the study.

\section{Results}

The 973 patients infected with HCV were enrolled and treatment response was monitored in each patient properly. Among these, 41 patients discontinue the treatment. All patients were divided into two groups depending on type of treatment that was IFN based therapy $(n=374)$ and direct acting antivirals $(\mathrm{n}=558)$ as shown in Figure 1.

The effects of antivirals drugs were monitored with comparison to gender and isolated genotypes for first six months of starting the treatment. Highest viral load was seen in males and female who were infected with mixed genotypes (3a/2b), while low in genotype 3a infected cases. Rate of recurrence was high in males infected with mixed genotype (3a/2b) as compared to females. There were no recurrence of $\mathrm{HCV}$ in males and females infected with genotype 3a. The high rate of recurrence was noted in female as compared to male patients infected with genotype $2 \mathrm{~b}$ after six months of therapy. The overall viral load was low in males infected with genotype $2 \mathrm{~b}$ compared to females, while rate of recurrence was much important at this stage. Significant response of antiviral therapy was noted against genotype 3 a after 3 month of use (see Figure 2).

The peg interferon based treatment was given to 374 (40.1\%) patients out of 932 and there was a detectable HCV RNA (IU/ml) in 32 (3.4\%) patients after using therapy 


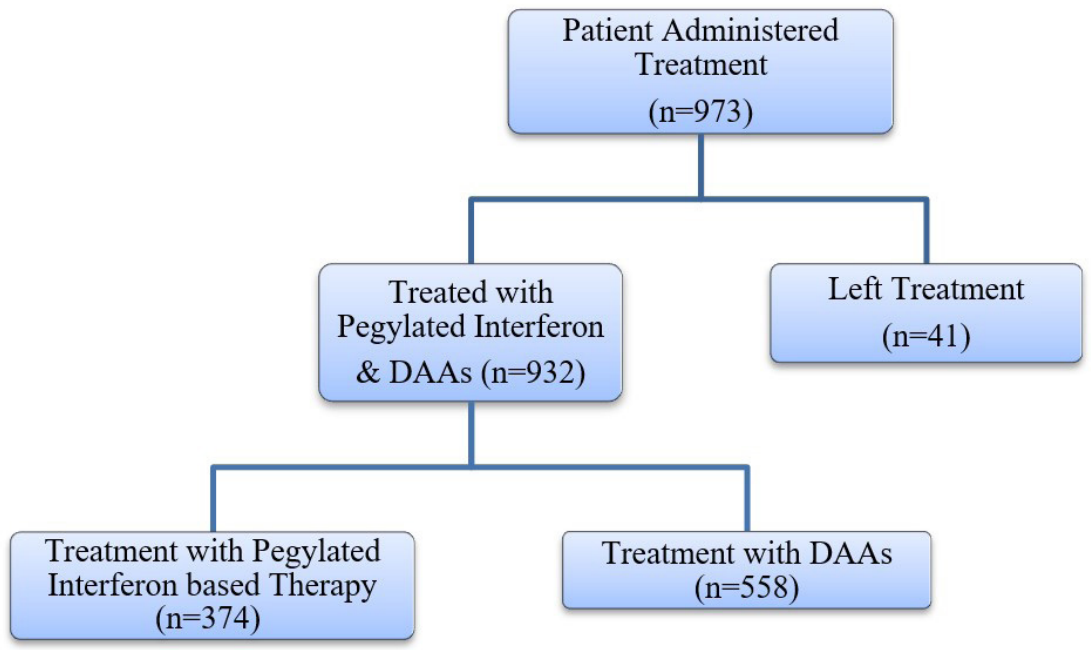

Figure 1. Flow of Enrolled Patients in the Study. DAAs (Direct Acting Antivirals).

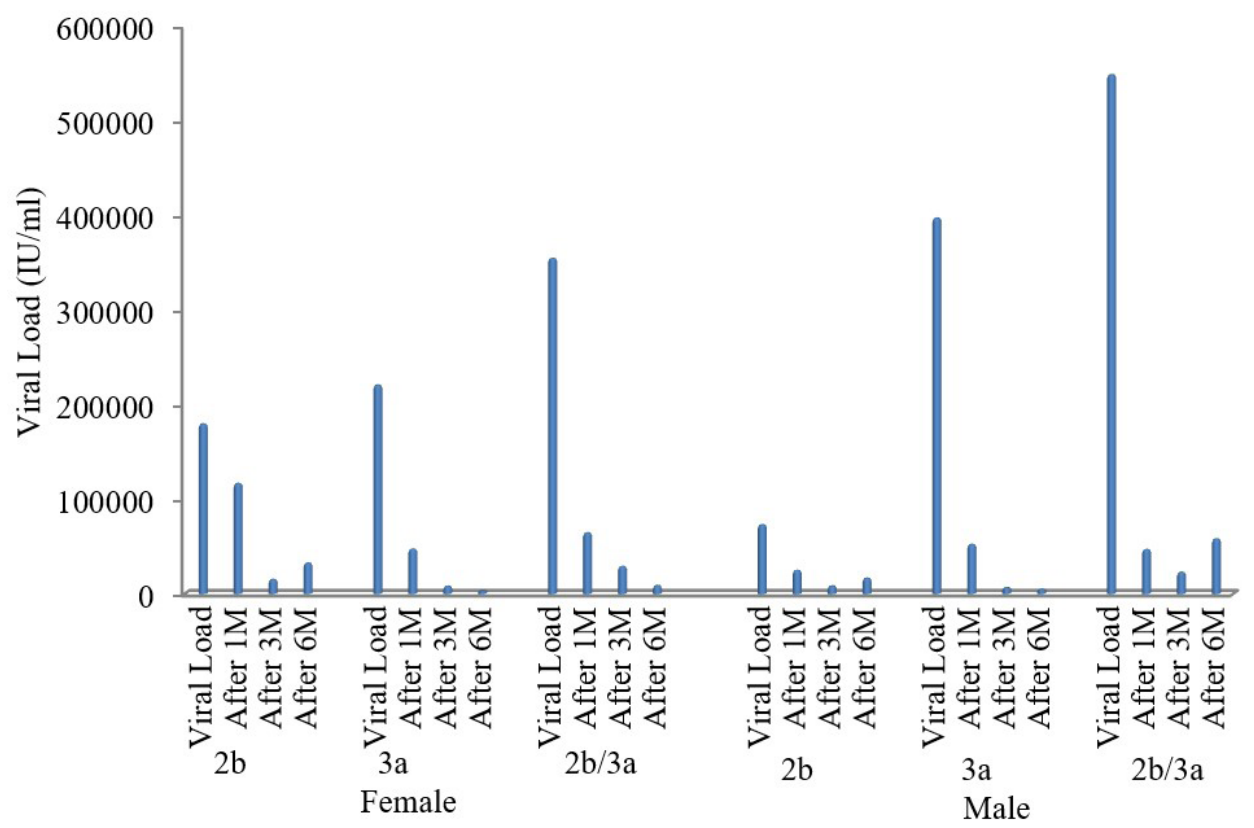

Figure 2. Recurrence Rate and Effect of Anti-HCV Therapy on Viral Load of Specific Genotype.

for 24 weeks. A set SVR was achieved in 342 cases with use of this therapy. Among these 32 (3.4\%) recurrent patients, the 29 cases were infected with the same genotype while 3 patients having the different genotypes (see Figure 3 ).

The DAAs were given to 558 (59.9\%)patients and early significant response to therapy was noted in first 2 weeks. Only 27 (4.8\%) cases having the detectable viral load (IU/ml) after 2 weeks of treatment. The 26 patients showed the same genotype, among these 27 (4.8\%) patients, while one patient was reinfected with different genotyep. Early and high response rate was noted DAAs therapy as shown in Figure 4.
A significant reduction in ALT level and viral load ( IU/ml) was noted in one week with DAAs therapy that was not achieved after 1 month with interferon based treatment. Although overall treatment response was highly significant $(P=0.000)$ in case of DAAs and interferon based therapies. Early and sustained virological response noted using DAAs for one week that was not achieved with interferon based treatment for 4 weeks as shown in Table 1.

The patients who achieved SVR for first six months were not at risk of recurrence in future as compared to those who did not achieve SVR during first six month 


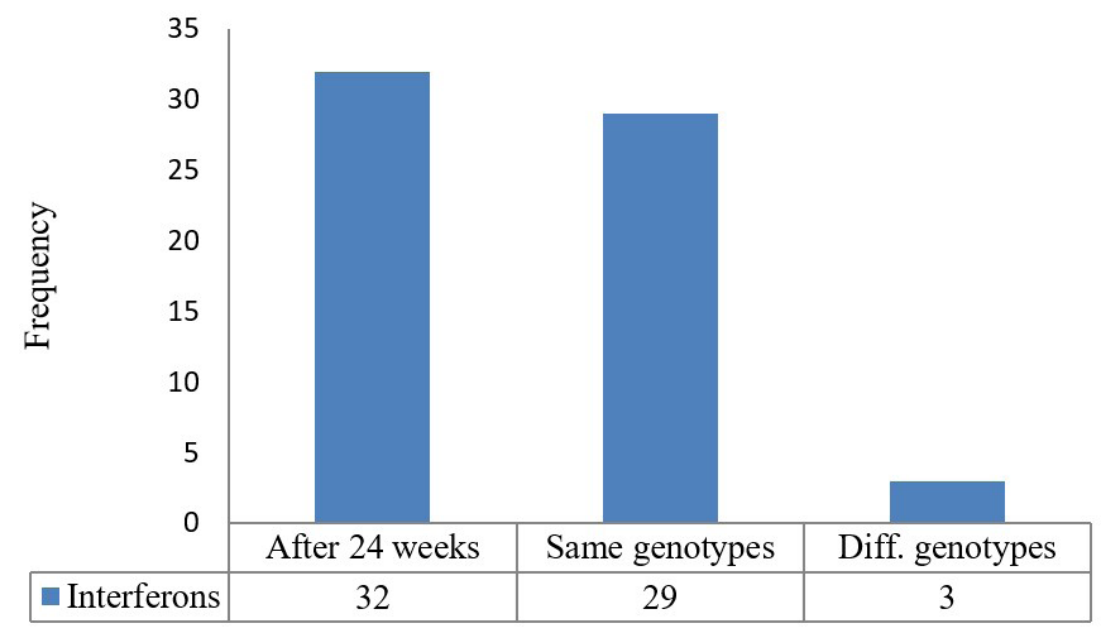

Figure 3. Response of Interferon Therapy after 24 Weeks of Treatment and Number of Non-responder along with Genotypes.

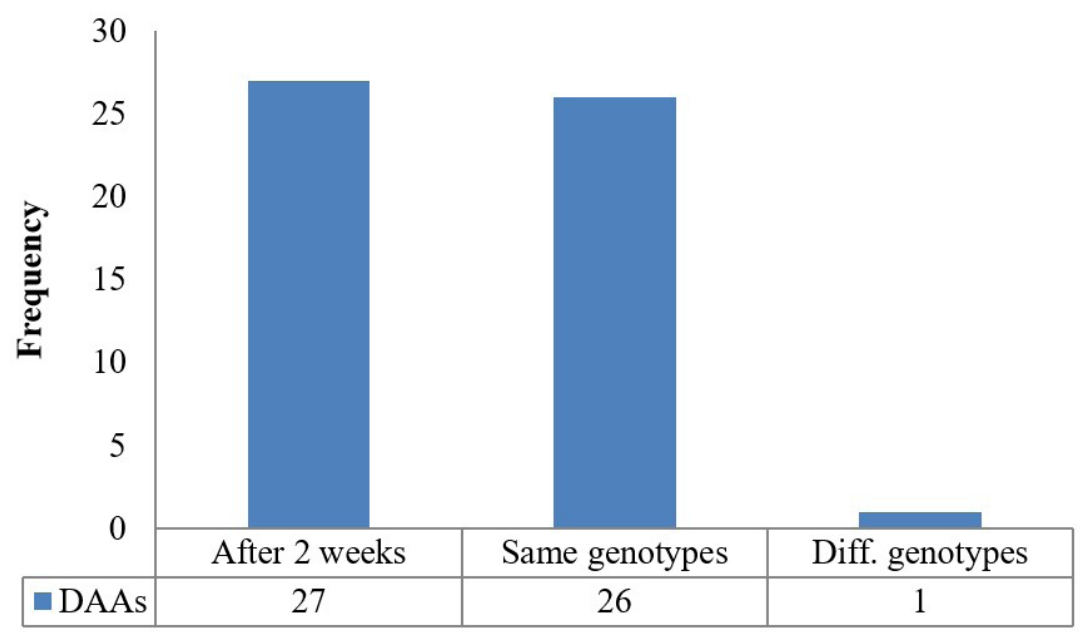

Figure 4. Response of DAAs after 2 Weeks of Treatment and Number of Non-responder along with Genotypes.

Table 1. The Treatment Efficiency of DAAs and Interferon on ALT and Viral Load by Pearson Chi-Square.

\begin{tabular}{cccccc}
\hline Parameters & Before treatment & $\begin{array}{c}\text { After 1 week } \\
\text { (DAAs) }\end{array}$ & $\begin{array}{c}\text { After 4 weeks } \\
\text { (Interferons) }\end{array}$ & All & P value \\
\hline ALT & 261 & 83 & 137 & 481 & 0 \\
& 54.26 & 17.26 & 28.48 & 100 & \\
& 0.059 & 0.484 & 0.097 & 0.08 & 0 \\
Viral Load (IU/ml) & 0.044 & 0.014 & 0.023 & 0.08 & 598920 \\
& 440500 & 17050 & 141370 & 100 & 0 \\
& 73.55 & 2.86 & 23.6 & 99.92 & 599401 \\
\end{tabular}




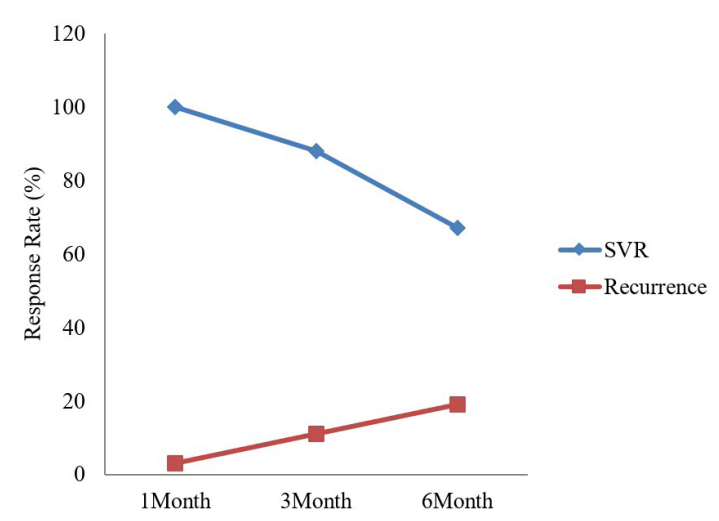

Figure 5. Changes in Sustained Virological Response and Rate of Recurrence in Six Months.

of treatment. Rate of recurrence increased when SVR decreased to 70\% (see Figure 5).

\section{Discussion}

The present study was designed to evaluate the recurrence of hepatitis $C$ virus after treatment with Direct Acting Antivirals and interferon based therapy in Punjab, Pakistan. Our study showed 95\% sustained virological response with DAAs in first 2 weeks of treatment while other study showed that sustained virological response with DAAs was $85 \%$ in HCV genotype 3 infected cases who received therapy for 24 weeks (Zeuzem et al., 2014). Another study concluded that DAAs therapy achieved 96.5\% early virological response to HCV genotype 3 patients. Hence, our findings are closer to Akhter et al. (2016), while highest and early response rate of DAAs as reported by Zeuzem et al., 2014. Different factors effects the rate of response of interferon based treatment including the age of patient, liver condition, viral load, viral genotype and treatment history (Aziz et al., 2012), this study supports our findings. In present study, we analyzed the factors effecting the response of treatment and their outcomes by using important parameters like ALT and viral load along with duration of treatment. Early and sustained virological response was achieved with DAAs in short duration that was not achieved by interferon therapy after long time. In Scandinavian countries, the injected DAAs to HCV genotype 3 patients and noted Sustained virological response in cirrhotic and non-cirrhotic patients that was $90 \%$ and 100 (Dalgard et al., 2017), supporting our finding. In our study, the rate of recurrence was high in patient infected with genotype $2 \mathrm{~b}$ and no significant SVR was noted which is contrary to the finding of Kanda et al. (2017), they showed that Sofosbuvir and Ribavirin therapy achieved sustained virological response of $90.4 \%$ among hepatitis $C$ virus genotype 2 in Japan. The viral load is an important indicator for examine of sustained virological response in those who are on Interferon therapy (Aziz et al., 2012). We have also set the viral load as an important parameter to check the SVR in patients who were on DAAs and interferon based therapy. The duration of therapy was an important factor in both cases. Early and sustained virological response was present with DAAs as compared to interferon-based therapy and rate of recurrence of HCV infection was high in case of interferon-based therapy as compared to DAAs.

WHO has announced to achieve the target of treating $80 \%$ of hepatitis C virus cases until 2030 . So, it is highly needed to evaluate those patients that have chronic HCV and to admit all these patients in treatment program. The price of drug (DAAs) is main treatment hurdle in Pakistan like other Countries (Hill et al., 2016). The Pakistan is placed at 149 out of 188 countries are trying towards sustained developmental goals in health related issues (Ilyas, 2016). Presently, the People of Pakistan are living at second highest load of hepatitis $C$ virus among the entire world. The present treatment response is $1 \%$ and all efforts of government for treatment of HCV patients are negligible instead of such high alarming situation as more than 10 million patients are infected. There is terrible requirement to provide the DAAs in hepatitis control and treatment programs.

\section{Conclusion}

Our study concluded that rate of recurrence was high in male infected with mixed genotype ( $3 a / 2 b)$ and female with genotype $2 \mathrm{~b}$. Early and sustained virological response appears in DAAs along with reduction in ALT and viral load. This study emphasize on use of DAAs in every health sector working on treatment of HCV. Therefore, reinfection require correct treatment efficiency and to select optimal strategies for retreatment cases.

\section{Acknowledgements}

We are highly thankful to Prof. Dr. Nasir Ali (Vice Principal), Nawaz Sharif Medical College, Gujrat, Punjab, Pakistan for providing the kind guidance in manuscript preparation and contacting with various treatment centers.

\section{References}

AKHTER, T.S., UMAR, M., KHAAR, H.T., ASLAM, F., NISAR, G., NASEER, A., AHMAD, S. and OSAMA, M., 2016. Sofosbuvir for the treatment of hepatitis $C$ genotype 3 infected patients in Pakistan. Journal of Ayub Medical College, Abbottabad, vol. 28, no. 4, suppl. 1, pp. S884-S889. PMid:28782338.

AZIZ, H., RAZA, A., WAHEED, Y., GILL, U. and GILL, M.L., 2012. Analysis of variables and interactions among variables associated with a sustained virological response to pegylated interferon alfa-2a plus ribavirin in hepatitis $C$ virus genotype 3 -infected patients. International Journal of Infectious Diseases, vol. 16, no. 8, pp. e597-e602. http://dx.doi.org/10.1016/j.ijid.2012.03.012. PMid:22658873.

DALGARD, O., WEILAND, O., NORABERG, G., KARLSEN, L., HEGGELUND, L., FÄRKKILÂ, M., BALSLEV, U., BELARD, E., ØVREHUS, A., KJÆR, M. S., KRARUP, H., RøGE, B. T., HALLAGER, S., MADSEN, L.G., LAURSEN, A. L., LAGGING, M. and WEIS, N., 2017. Sofosbuvir based treatment of chronic hepatitis $C$ genotype 3 infections: a scandinavian real-life study. PLoS One, 
vol. 12, no. 7, pp. e0179764. http://dx.doi.org/10.1371/journal. pone.0179764. PMid:28704381.

HILL, A., SIMMONS, B., GOTHAM, D. and FORTUNAK, J., 2016. Rapid reductions in prices for generic sofosbuvir and daclatasvir to treat hepatitis C. Journal of Virus Eradication, vol. 2, no. 1, pp. 28-31. http://dx.doi.org/10.1016/S2055-6640(20)30691-9. PMid:27482432.

ILYAS, F., 2016. [viewed 23 September 2016]. Pakistan ranked 149th in UN health goals [online]. Dawn. Available at https://www. dawn.com/news/1285528.

KANDA, T., NAKAMURA, M., YASUI, S., HAGA, Y., TAWADA, A., SUZUKI, E., OOKA, Y., TAKAHASHI, K., SASAKI, R., WU, S., NAKAMOTO, S., ARAI, M., IMAZEKI, F. and YOKOSUKA, O., 2017. Treatment of real-World HCV genotype 2-infected Japanese patients with sofosbuvir plus ribavirin. Biology, vol. 6, no. 2, pp. 30. http:// dx.doi.org/10.3390/biology6020030. PMid:28486403.

MESSINA, J.P., HUMPHREYS, I., FLAXMAN, A., BROWN, A., COOKE, G.S., PYBUS, O.G. and BARNES, E., 2015. Global distribution and prevalence of hepatitis C virus genotypes. Hepatology, vol. 61, no. 1, pp. 77-87. http://dx.doi.org/10.1002/hep.27259. PMid:25069599.

NAGHAVI, M., SHAHRAZ, S., SEPANLOU, S.G., DICKER, D., NAGHAVI, P., POURMALEK, F., MOKDAD, A., LOZANO, R., VOS, T., ASADILARI, M., SAYYARI, A.A., MURRAY, C.J. and FOROUZANFAR, M.H., 2014. Health transition in Iran toward chronic diseases based on results of Global Burden of Disease 2010. Archives of Iranian Medicine, vol. 17, no. 5, pp. 321-335. PMid:24784861.

OMATA, M., KANDA, T., WEI, L., YU, M., CHUANG, W., IBRAHIM, A., LESMANA, C.R.A., SOLLANO, J., KUMAR, M., JINDAL, A., SHARMA, B.C., HAMID, S.S., DOKMECI, A.K., MAMUN-ALMAHTAB., MCCAUGHAN, G.W., WASIM, J., CRAWFORD, D.H.G., KAO, J.H., YOKOSUKA, O., LAU, G.K. and SARIN, S.K., 2016. APASL consensus statements and recommendation on treatment of hepatitis C. Hepatology International, vol. 10, no. 5, pp. 702-726. http://dx.doi.org/10.1007/s12072-016-9717-6. PMid:27130427.

SAEED, U., WAHEED, Y., ASHRAF, M., WAHEED, U., ANJUM, S. and AFZAL, M.S., 2015. Estimation of hepatitis B virus, hepatitis $C$ virus, and different clinical parameters in the thalassemic population of Capital Twin Cities of Pakistan. Virology, vol. 6, pp. 11-16. PMid:26568681.
SMITH, D.B., BUKH, J., KUIKEN, C., MUERHOFF, A.S., RICE, C.M., STAPLETON, J.T. and SIMMONDS, P., 2014. Expanded classification of hepatitis $C$ virus into 7 genotypes and 67 subtypes: updated criteria and genotype assignment web resource. Hepatology, vol. 59, no. 1, pp. 318-327. http://dx.doi.org/10.1002/hep.26744. PMid:24115039.

WAHEED, Y., 2015a. Effect of interferon plus ribavirin therapy on hepatitis $C$ virus genotype 3 patients from Pakistan: treatment response, side effects and future prospective. Asian Pacific Journal of Tropical Medicine, vol. 8, no. 2, pp. 85-89. http:// dx.doi.org/10.1016/S1995-7645(14)60193-0. PMid:25902019.

WAHEED, Y., 2015b. Transition from millennium development goals to sustainable development goals and hepatitis. Pathogens and Global Health, vol. 109, no. 8, pp. 353. http://dx.doi.org/10.108 0/20477724.2015.1126035. PMid:26924344.

WAHEED, Y., NAJMI, M.H., AZIZ, H., WAHEED, H., IMRAN, M. and SAFI, S.Z., 2017. Prevalence of hepatitis $C$ in people who inject drugs in the cities of Rawalpindi and Islamabad, Pakistan. Biomedical Reports, vol. 7, no. 3, pp. 263-266. http://dx.doi. org/10.3892/br.2017.959. PMid:28894573.

WAHEED, Y., SHAFI, T., SAFI, S.Z. and QADRI, I., 2009. Hepatitis C virus in Pakistan: a systematic review of prevalence, genotypes and risk factors. World Journal of Gastroenterology, vol. 15, no. 45, pp. 5647-5653. http://dx.doi.org/10.3748/wjg.15.5647. PMid: 19960560.

WORLD HEALTH ORGANIZATION - WHO, 2016 [viewed 17 May 2016]. Global health sector strategies on viral hepatitis 20162021 [online]. Available at https:// https://www.who.int/ publications/i/item/WHO-HIV-2016.06.

WORLD HEALTH ORGANIZATION - WHO, 2017. Global hepatitis report 2017 [online]. Available at https://apps.who.int/iris/ handle/10665/255016.

ZEUZEM, S., DUSHEIKO, G.M., SALUPERE, R., MANGIA, A., FLISIAK, R., HYLAND, R.H., ILLEPERUMA, A., SVAROVSKAIA, E., BRAINARD, D.M., SYMONDS, W.T., SUBRAMANIAN, G.M., MCHUTCHISON, J.G., WEILAND, O., REESINK, H.W., FERENCI, P., HÉZODE, C. and ESTEBAN, R., 2014. Sofosbuvir and ribavirin in HCV genotypes 2 and 3. The New England Journal of Medicine, vol. 370, no. 21, pp. 1993-2001. http://dx.doi.org/10.1056/NEJMoa1316145. PMid:24795201. 